\title{
Evaluation of heavy metals in tissue of Tympanotonus fuscatus sold in some markets in Port Harcourt metropolis, Nigeria
}

\begin{abstract}
Tympanotonus fuscatus is found in mangrove swamps of the coastal region of the Niger Delta Nigeria. It is a source of protein, Hence it is used in the preparation of delicacies. This study evaluated the level of heavy metals in tissues of Tympanotonus fuscatus sold in some markets in Port Harcourt, Rivers state, Nigeria. Triplicate samples of Tympanotonus fuscatus was purchased from seven different markets within Port Harcourt metropolis. The samples were digested and analyzed using a Flame atomic absorption spectrometer. Results showed that the concentration of the heavy metals ranged from $0.76-1.56 \mathrm{mg} / \mathrm{kg}$ (nickel), $22.36-29.28 \mathrm{mg} / \mathrm{kg}$ (zinc), $185.07-921.49 \mathrm{mg} / \mathrm{kg}$ (iron), $0.05-0.56 \mathrm{mg} / \mathrm{kg}$ (lead), $80.96-102.62 \mathrm{mg} / \mathrm{kg}$ (cobalt) and $19.04-69.45 \mathrm{mg} / \mathrm{kg}$ (manganese). Moisture and organic matter contents ranged from $78.88-85.87 \%$ and $86.06-92.23 \%$ respectively. Analysis of variance showed that there is significant difference $(\mathrm{P}<0.05)$ in most of the locations for each of the parameters. The variation that exists could be due to differences in the pollution load of the aquatic habitats from which the samples were harvested. Based on permissible limit, the heavy metals concentration were within allowable limit for fish-food specified by Food and Agricultural Organization/World Health Organization, Median International Standard and European Union except for iron, manganese and copper. The high level of iron, manganese and copper suggests potential health effects.
\end{abstract}

Keywords: aquatic pollution, environmental health, fish food, heavy metals, Tympanotonus fuscatus
Volume 4 Issue 5 - 2018

\author{
Ayobami Omozemoje Aigberua,' Sylvester \\ Chibueze Izah $^{2}$ \\ 'Department of Chemical Sciences, Niger Delta University, \\ Nigeria \\ ${ }^{2}$ Department of Biological Sciences, Niger Delta University, \\ Nigeria
}

Correspondence: Sylvester C Izah, Department of Biological Sciences, Faculty of Science, Niger Delta University, Wilberforce Island, Bayelsa State, Nigeria, Tel +2347030192466, Email chivestizah@gmail.com

Received: December 22, 2017 | Published: September 25, 2018

\section{Introduction}

Several invertebrate species are found in aquatic ecosystem in the Niger Delta. In addition, Niger Delta is home of several fish species including shelled and fin fish. Some of the common shell fish found in the region is univalve gastropods that belong to the Mollusca phyla. Periwinkles are a typical example of shelled fish which is found predominantly in the littoral region of the marine and estuarine habitats having mangrove plants. ${ }^{1-4}$ Periwinkles predominantly belong to three genus including Tympanotonus, Pachymelania and Merceneria. ${ }^{1}$ Of the three genera, species of periwinkle that belong to the Tympanotonus and Pachymelania genera are predominant in the Niger Delta region of Nigeria. ${ }^{1}$ As such, the two predominant species of periwinkle are found in fresh and salt water interphase (brackish water) habitat and benthos of the Niger Delta. But the two species are phenotypically different. For instance, Pachymelania aurita has sharp spines (which depend on the age of the species) and broader aperture, while the species Tympanotonus fuscatus has turreted, granular and spiny shells with tapering ends. ${ }^{1}$

Specifically, Tympanotonus fuscatus concentrate under the roots and decaying red mangrove trees and small collection of water during low tide. ${ }^{1}$ Hence, their population depends on their quest for food and shelter. ${ }^{1}$ The flesh of Tympanotonus fuscatus is used in the preparation of delicacies in the Niger Delta region. ${ }^{4,5}$ While the shell is used for construction works especially in coastal communities close to the mangroves. Being a source of food to several families, there is the need to assess the level of undesirable substances in their tissues due to level of environmental pollution in the aquatic ecosystems. According to Otitoju and Otitoju, ${ }^{5}$ the environment where food-based aquatic Mollusca are harvested from gives reasons to worry.

According to Ogamba et al., ${ }^{4}$ Izah \& Angaye, ${ }^{6}$ the intensity of environmental contaminants has increased. This is probably due to industrialization, population growth, urbanization without adequate management and planning strategy. Pollution emanates from several human activities and to a lesser extent natural effects such as weathering. Pollution often emanates from the activities of oil and gas industries, which tend to spread fast and wide when in aquatic environment. ${ }^{7}$ Agricultural activities (use of pesticides and agrochemicals), marketing, food processing, municipal solid wastes and effluents resulting from several chemical industries are other sources of environmental pollution. During rainfall, the constituent of these wastes streams could be washed off or leached into nearby pools of water and/or surface waters, where it could affect the biota in such aquatic ecosystem.

Wastes are major source of environmental heavy metals pollution. This happens when the wastes are improperly discharged. According to Obasi et al., ${ }^{8}$ condemned batteries and bathroom effluents are possible source of water pollution. Okuo et al.,9 reported that the mining, dumping of dangerous military wastes and carcasses of old 
damaged vehicles are some of the sources of heavy metal pollution on soil. This heavy metals have the tendency to bioaccumulate and become very toxic ${ }^{9}$ especially when their concentrations exceed the allowable limit in such environment.

Heavy metals have adverse environmental and public health importance. ${ }^{10}$ Typically, heavy metals are grouped into essential (elements required at certain concentrations for maintenance of life) and non-essential (not required by the body even at low concentrations). When the concentration of essential heavy metals such as iron, copper, zinc, manganese etc exceeds the recommended limit, it could be deleterious to the body just as the non-essential heavy metals such as arsenic, lead, cadmium and mercury. As such, most heavy metals are toxicants that could induce multiple organ damage. ${ }^{10}$ For instance, lead has the tendency to interfere with several enzymatic functions and physiological processes in the human body there by affecting the nervous, reproductive, cellular and cardiac systems. ${ }^{8}$ The effects of several heavy metals to the different tissues and organs have been previously described by Izah et al. ${ }^{11}$

Due to the ability of Tympanotonus fuscatus to bioaccumulate toxicants such as heavy metals in their environment and its role in human nutrition, several studies have been carried out on the heavy metals concentration in Tympanotonus fuscatus from several locations in the Niger Delta. Some of these studies were carried out in Qua Iboe River Basin, Ibeno, Akwa Ibom State, ${ }^{12}$ Elechi Creek, Rivers state, ${ }^{13}$ Warri River, Delta state, ${ }^{14,15}$ In Eagle Island River, Rivers State, ${ }^{8,16}$ Nembe in Nembe Local Government Area and Lobia in Southern Ijaw Local Government Area of Bayelsa, ${ }^{4}$ Oron River in Idia-oro, Oron Local Government area of Akwa-Ibom state, Itu River in Ikot-Udobia in North-western part of Akwa-Ibom state and Abuloma River, PortHarcourt, Rivers state, ${ }^{5}$ Egbokodo River, Warri, Delta state. ${ }^{17}$

The Tympanotonus fuscatus sold in some major markets are obtained from different sources and variation exists in pollution level of their different habitats. There is the need to assess the level of heavy metals in aquatic food proteins sold in our local markets. Therefore, this study focused on the heavy metals in tissues of Tympanotonus fuscatus sold in some markets in Port Harcourt metropolis, Nigeria.

\section{Materials and methods}

\section{Sample collection, preparation and analysis}

Triplicate tissue samples of Tympanotonus fuscatus were purchased from seven markets within the Port Harcourt metropolis, Rivers state, Nigeria. The Tympanotonus fuscatus samples were transported to the laboratory in an ice chest. The samples were washed using sterile water and thereafter dried in oven at $105^{\circ} \mathrm{C}$ for 6 hours. ${ }^{18}$ The samples were blended to powder, dry-ashed in a muffle furnace at $450^{\circ} \mathrm{C}$. Thereafter, the samples were digested using $5 \mathrm{ml}$ of $10 \%$ nitric (sp. gr 1.42 ) and $5 \mathrm{ml}$ of $10 \%$ hydrochloric acid (sp. gr 1.19) which was added separately. The respective solutions of ash were transferred into $100 \mathrm{ml}$ pyrex beakers with about $20 \mathrm{ml}$ distilled water washings and covered with ribbed watch glasses before being heated at $95^{\circ} \mathrm{C}$ on a hot plate until the mixture was concentrated to about $10 \mathrm{ml}$. The concentrated ash solution was allowed to cool at room temperature. The content was filtered and quantitatively transferred into a $50 \mathrm{ml}$ volumetric flask before being diluted to mark with distilled water. The ash solution was analyzed using Flame Atomic Absorption Spectrometer (GBC Avanta PM A6600). The instrument was calibrated prior to sample aspiration with a series of prepared standard solutions of the respective metals of interest. The metals were analyzed at varying wavelengths of 213.9 $\mathrm{nm}, 324.70 \mathrm{~nm}, 232.0 \mathrm{~nm}, 248.3 \mathrm{~nm}, 279.5 \mathrm{~nm}, 357.90 \mathrm{~nm}, 228.8 \mathrm{~nm}$, $217.00 \mathrm{~nm}$ and $240.70 \mathrm{~nm}$ for zinc, copper, nickel, iron, manganese, chromium, cadmium, lead and cobalt respectively. ${ }^{18-21}$ The moisture and organic matter content of the samples were gravimetrically analyzed as previously described by Horsfall et al. ${ }^{22}$

\section{Statistical analysis}

SPSS software version 20 was used to carry out the statistical analysis. Data were expressed as mean \pm standard deviation. A oneway analysis of variance was carried out at $\mathrm{P}=0.05$, and WallerDuncan multiple range test statistics was used to determine the source of the observed difference. Spearman rho correlation matrix was used to show relationship among the various parameters under study.

\section{Results and discussion}

Table 1 presents moisture content, organic matter content and heavy metal levels in tissue of Tympanotonus fuscatus sold in some markets within the Port Harcourt metropolis, Nigeria. The spearman rho correlation matrix of parameters under study is presented in Table 2. Among the heavy metals studied, chromium, cobalt and cadmium were not detected. The findings of this study is contrary to the earlier findings of Otitoju and Otitoju ${ }^{5}$ that reported cadmium in the range of $0.11-0.27 \mathrm{mg} / \mathrm{kg}$, but comparable to the result of chromium i.e. $<0.001 \mathrm{mg} / \mathrm{kg}$ (not detected). Furthermore, the reported cadmium and chromium level of this study is also contrary to the previous findings of Ijeomah et al. ${ }^{7}$

The concentration of heavy metals depicted the following trends: nickel ranged from $0.76-1.56 \mathrm{mg} / \mathrm{kg}$, being significantly different $(\mathrm{P}<0.05)$ in most of the markets. Nickel showed positive significant correlation with lead $(\mathrm{r}=0.604, \mathrm{P}<0.01)$ and manganese $(\mathrm{r}=0.488, \mathrm{P}<0.05)$, and negatively correlated with organic matter $(\mathrm{r}=-0.631, \mathrm{P}<0.01)$. Zinc concentration ranged from $22.36-29.28 \mathrm{mg} /$ $\mathrm{kg}$. There was no significant difference $(\mathrm{P}>0.05)$ among the various markets of study. Zinc showed positive significant relationship with moisture $(r=0.463, \mathrm{P}<0.05)$ and organic matter $(\mathrm{r}=0.482, \mathrm{P}<0.05)$. Iron concentration ranged from $185.07-921.49 \mathrm{mg} / \mathrm{kg}$. There was significant variation $(\mathrm{P}<0.05)$ among the samples from the various markets. Iron showed positive significant correlation with manganese $(\mathrm{r}=0.579, \mathrm{P}<0.01)$. Lead concentrations ranged from $0.05-0.56 \mathrm{mg} /$ $\mathrm{kg}$, being significantly different $(\mathrm{P}<0.05)$ among the various markets. Lead showed positive significant relationship with iron $(\mathrm{r}=0.544)$ and manganese $(\mathrm{r}=0.524)$, and negatively correlated with moisture $(\mathrm{r}=-0.487)$ and organic matter $(\mathrm{r}=0.491)$ at $\mathrm{P}<0.01$. Copper and manganese concentration in the tissues of Tympanotonus fuscatus within the study area ranged from $80.96-102.62 \mathrm{mg} / \mathrm{kg}$ and 19.04 $69.45 \mathrm{mg} / \mathrm{kg}$ respectively. Basically, there was significant difference $(\mathrm{P}<0.05)$ among the various markets for each of the metals. Moisture and organic matter content of the tissues of Tympanotonus fuscatus in the study area ranged from $78.88-85.87 \%$ and $86.06-92.23 \%$ respectively. Typically, there was significant difference $(\mathrm{P}<0.05)$ among the various markets for both parameters. Moisture showed positive significant relationship with organic matter $(\mathrm{r}=0.709$, $\mathrm{P}<0.01$ ). The positive correlation between moisture and organic matter content is an indication that both parameters are from similar source. The significant positive relationship which zinc depicted with moisture and organic matter is an indication that the moisture plays an essential role in the bio-concentration of zinc by Tympanotonus fuscatus in their habitats.

The variation in the heavy metals, organic matter and moisture 
content of Tympanotonus fuscatus sold in some major markets within the Port Harcourt metropolis could be due to differences in their source and pollution levels across their different habitats. Typically, pollution in aquatic ecosystems which is majorly caused by anthropogenic activities, which is a threat to biota species of the aquatic ecosystem. Pollution is caused as a result of chemical pollutants from industrial, domestic and agricultural wastes. ${ }^{5}$ This waste occurs in different dimensions. For instance, agricultural wastes resulting from the use of pesticides and other agrochemicals in fields close to aquatic ecosystem end up in the available surface waters. ${ }^{5,23-25}$ Obasi et al., ${ }^{8}$ reported that the disposal of condemned car batteries, metals and metal components into surface water, leaching of metals from garbage and solid wastes, effluents from bathroom is another possible source of surface water pollution. Furthermore, pier toilet system is also used in many coastal communities in the Niger Delta. In addition, municipal wastes, market wastes are also deposited in close-by surface waters. ${ }^{6,26-31}$ Tympanotonus fuscatus is found in intertidal areas and estuarine characterized by mangroves such as Rhizophora racemosa, R. mangle, Avicennia Africana, Nypafruticans, Laguncularia racemosa, etc., In the Niger Delta, the mangroves are also a home of several oil and gas installations. Ijeomah et al., ${ }^{7}$ reported that Oil spillage has been implicated as the major cause of environmental pollution in oil producing areas in Nigeria. Therefore, pollution associated with oil and gas activities in addition to pollution caused by wastes discharged into the aquatic ecosystem could be another source of heavy metals in the tissues. Because Tympanotonus fuscatus inhabits in the detritus rich mud substratum in quiet water it has the tendency to absorb toxicants from its environment (i.e. water and sediment). ${ }^{2,4,8}$ Obasi et al., ${ }^{8}$ reported that the presence of

Table I Moisture content, Heavy metal and organic matter content in tissue of Tympanotonus fuscatus sold in some markets within Port Harcourt metropolis, Nigeria

\begin{tabular}{|c|c|c|c|c|c|c|c|c|}
\hline Markets & $\begin{array}{l}\text { Nickel, } \\
\text { (mg/kg) }\end{array}$ & $\begin{array}{l}\text { Copper, (mg/ } \\
\text { kg) }\end{array}$ & $\begin{array}{l}\text { Zinc, (mg/ } \\
\text { kg) }\end{array}$ & $\begin{array}{l}\text { Lead, } \\
\text { (mg/kg) }\end{array}$ & Iron, (mg/kg) & $\begin{array}{l}\text { Manganse, } \\
\text { (mg/kg) }\end{array}$ & $\begin{array}{l}\text { Moistue } \\
(\%)\end{array}$ & $\begin{array}{l}\text { Organic } \\
\text { Matter (\%) }\end{array}$ \\
\hline Eneka & $0.76 \pm 0.03 \mathrm{a}$ & $93.77 \pm 0.57 \mathrm{c}$ & $26.45 \pm 1.16 \mathrm{ab}$ & $0.09 \pm 0.0 \mathrm{a}$ & $409.49 \pm 2.07 \mathrm{~d}$ & $25.17 \pm 1.74 \mathrm{ab}$ & $85.16 \pm 0.01 \mathrm{c}$ & $90.40 \pm 0.23 \mathrm{~d}$ \\
\hline Oil mill & $1.11 \pm 0.06 \mathrm{ab}$ & $89.73 \pm 1.17 b c$ & $26.66 \pm 0.85 \mathrm{ab}$ & $0.07 \pm 0.0 \mathrm{a}$ & $292.56 \pm 3.81 \mathrm{c}$ & $59.12 \pm 4.17 \mathrm{~d}$ & $85.87 \pm 0.01 \mathrm{e}$ & $88.53 \pm 0.26 \mathrm{c}$ \\
\hline Rumuodai & $1.47 \pm 0.23 b$ & $81.43 \pm 0.73 \mathrm{a}$ & $27.02 \pm 1.14 \mathrm{ab}$ & $0.15 \pm 0.0 \mathrm{~b}$ & $507.70 \pm 3.86 \mathrm{f}$ & $31.48 \pm 0.57 b$ & $83.03 \pm 0.02 b$ & $86.97 \pm 0.08 \mathrm{~b}$ \\
\hline Rumuokwurushi & $1.56 \pm 0.26 b$ & $80.96 \pm 1.14 \mathrm{a}$ & $25.53 \pm 1.81 \mathrm{ab}$ & $0.56 \pm 0.0 \mathrm{c}$ & $447.36 \pm 3.80 \mathrm{e}$ & $69.45 \pm 2.70 \mathrm{e}$ & $85.67 \pm 0.04 d$ & $88.15 \pm 0.09 \mathrm{c}$ \\
\hline Slaughter & $1.48 \pm 0.23 b$ & $93.74 \pm 2.10 \mathrm{c}$ & $22.36 \pm 1.29 a$ & $0.19 \pm 0.0 \mathrm{~b}$ & $220.58 \pm 4.05 b$ & $23.80 \pm 1.69 \mathrm{ab}$ & $78.88 \pm 0.07 \mathrm{a}$ & $86.06 \pm 0.03 \mathrm{a}$ \\
\hline Elimgbu/Tank & $0.82 \pm 0.06 \mathrm{a}$ & $86.27 \pm 1.08 \mathrm{~b}$ & $27.67 \pm 1.51 b$ & $0.05 \pm 0.0 \mathrm{a}$ & $185.07 \pm 2.91 \mathrm{a}$ & $19.04 \pm 0.69 \mathrm{a}$ & $85.87 \pm 0.04 \mathrm{e}$ & $92.98 \pm 0.26 f$ \\
\hline Woji Market & $1.13 \pm 0.08 \mathrm{ab}$ & $102.62 \pm 0.95 d$ & $29.28 \pm 1.42 b$ & $0.18 \pm 0.0 \mathrm{~b}$ & $921.49 \pm 14.47 \mathrm{~g}$ & $41.23 \pm 1.86 \mathrm{c}$ & $85.68 \pm 0.05 d$ & $92.23 \pm 0.13 \mathrm{e}$ \\
\hline
\end{tabular}

Each value is expressed as mean \pm standard error $(n=3)$. Different alphabets along the column indicate significant difference $(P<0.05)$ according to Duncan statistics.

heavy metals in Tympanotonus fuscatus could be due to their ability to bioaccumulate within the food chain.

Based on the recommended limits for fish-food, lead, cadmium in this study is within European Union limit. ${ }^{6,32-34}$ In addition to lead and cadmium, chromium and zinc was also found within median international standard previously recommended by authors ${ }^{6,34-35}$ and FAO/WHO reference limit. ${ }^{6,36,37}$ Iron, manganese, copper was higher than WHO allowable limit. ${ }^{38,39}$ Furthermore, copper was higher than Median International Standard, ${ }^{33-}{ }^{35}$, FAO/WHO. ${ }^{36,37}$ Cobalt was not detected in the fish food while nickel concentration is quite insignificant to cause major harmful effect on consumers.

The result of the heavy metals depicted the following order: $\quad$ chromium $=$ cadmium $=$ cobalt $<$ lead $<$ nickel $<$ zinc $<$ manganese $<$ copper $<$ iron. The higher concentration in iron, copper, manganese and zinc in the tissues of Tympanotonus fuscatus followed a similar trend to Ijeomah et al. ${ }^{7}$ The authors reported that nonvertebrate fauna species such as Tympanotonus fuscatus have high affinity for iron, zinc, manganese and copper intake. As such, this may be associated to the role these essential heavy metals play in the organisms. ${ }^{7}$ Most of these essential heavy metals play essential role for enzymatic, physiological and metabolic processes, ${ }^{11}$ replacement of cells and activation of low immune system. ${ }^{7}$ Ijeomah et al., further reported that in iron, copper, manganese and zinc are cofactors for a larger number of enzymes. However, Excessive intake of these metals could constitute health risks. ${ }^{7}$ The pathological effects of heavy metals under study have been previously reported by Izah et al., ${ }^{11,40}$ Izah \& Angaye, ${ }^{6}$ Aigberua \& Tarawou. ${ }^{18}$ 
Table 2 Spearman rho correlation parameters under study

\begin{tabular}{|c|c|c|c|c|c|c|c|c|}
\hline Parameters & Nickel & Copper & Zinc & Lead & Iron & Manganese & Moisture & $\begin{array}{l}\text { Organic } \\
\text { matter }\end{array}$ \\
\hline Copper & -.344 & 1.000 & & & & & & \\
\hline Zinc & -.287 & .133 & 1.000 & & & & & \\
\hline Lead & $.604 * *$ & -.047 & -.167 & 1.000 & & & & \\
\hline Manganese & $.488^{*}$ & -.203 & .173 & $.524 *$ & $.579 * *$ & 1.000 & & \\
\hline Moisture & -.358 & -.053 & $.463 *$ & $-.487^{*}$ & -.198 & .220 & 1.000 & \\
\hline $\mathrm{OM}$ & $-.631 * *$ & .296 & $.482 *$ & $-.491 *$ & -.045 & -.192 & $.709 * *$ & 1.000 \\
\hline
\end{tabular}

**. Correlation is significant at the 0.01 level (2-tailed).

*.Correlation is significant at the 0.05 level (2-tailed).

$\mathrm{N}=2 \mathrm{I}, \mathrm{n}=3$

\section{Conclusion}

The study investigated the level of some selected heavy metals in tissues of Tympanotonus fuscatus sold in some markets within the Port Harcourt Metropolis, Rivers state, Nigeria. The study found that cobalt, cadmium and chromium were below detection limit of the instrument. While the levels of iron, manganese and cobalt exceeded the World Health Organization permissible limit for fish food. Therefore, caution should be exercised in the consumption of Tympanotonus fuscatus. Furthermore, surveillance should be carried out by Federal Environmental Protection Agency with regard to different categories of municipal and industrial wastes that are discharged into the environment in addition to wastes from oil and gas activities.

\section{Acknowledgements}

None.

\section{Conflict of interest}

The authors affirms that there are not conflict of interest.

\section{References}

1. Bob Manuel FG. A prelimenary study on the population estimation of the periwinkles Tympanotonus fuscatus (Linnaeus, 1758) and Pachymelania aurita (Muller) at the Rumuolumeni mangrove swamp creek, Niger Delta, Nigeria. Agriculture and Biology Journal of North America. 2012;3(6):265-270.

2. Jamabo N, Chinda A. Aspects of the Ecology of Tympanotonus fuscatus varfuscatus (Linnaeus, 1758) in the Mangrove Swamps of the Upper Bonny River, Niger Delta, Nigeria. Current Research Journal of Biological Sciences. 2010;2(1):42-47.

3. Egonmwan RI. Thermal thorelance and evaporative water loss of the mangrove prosobranch Tympanotonus fuscatus varradula L. (Cerithiacea: Potamididae). Pakistan Journal of Biological Sciences. 2007;10(1):163166.

4. Ogamba EN, Izah SC, Omonibo E. Bioaccumulation of hydrocarbon, heavy metals and minerals in Tympanotonus fuscatus from coastal region of Bayelsa state, Nigeria. International Journal of Hydrology Research. 2016;1:1-7.

5. Otitoju O, Otitoju GTO. Heavy metal concentrations in water, sediment and periwinkle (Tympanotonus fuscastus) samples harvested from the

Niger Delta region of Nigeria. African Journal of Environmental Science and Technology. 2013;7(5):245-248.

6. Izah SC, Angaye TCN. Heavy metal concentration in fishes from surface water in Nigeria: Potential sources of pollutants and mitigation measures. Sky Journal of Biochemistry Research. 2016;5(4):31-47.

7. Ijeomah HM, Edet DI, Oruh EK, et al. Assessment of Heavy Metals in Tissues of Selected Non-Vertebrate Wildlife Species in Oil Polluted Sites of Delta State, Nigeria. Agriculture and Biology Journal of North America. 2015;6(2):63-73.

8. Obasi KO, Chinedu K, Okereke JN, et al. Concentrations Of Cadmium, Lead, Arsenic And Mercury In The Soft Tissue Of Periwinkle( Tympanotonus Fuscata Var. Radula) In Eagle Island River, Rivers State , Nigeria. International Journal of Science and Technology. 2015;4(10):474-478.

9. Okuo James M, Okolo PO. Removal of Heavy Metal Ions by Blended Periwinkle Shells. Journal of Applied Sciences. 2006;6:567-571.

10. Freeman OE, Ovie OJ. Heavy Metal Bioaccumulation in Periwinkle (Tympanostomus Spp) and Blue Crab (Callinectes amnicola) Harvested from a Perturbed Tropical Mangrove Forest in the Niger Delta, Nigeria. Journal of Agriculture and Ecology Research International. 2017;11(1):112.

11. Izah SC, Chakrabarty N, Srivastav AL. A Review on Heavy Metal Concentration in Potable Water Sources in Nigeria: Human Health Effects and Mitigating Measures. Exposure and Health. 2016;8:285-304.

12. Andem AB, Udofia UU, Okorafor KA, et al. Bioaccumulation of some Heavy Metals and Total Hydrocarbon (THC) in the Tissues of Periwinkle (Tympanotonus fuscatus Varradula) in the Intertidal Regions of Qua Iboe River Basin, Ibeno, Akwa Ibom State, Nigeria. Greener Journal of Biological Sciences. 2013;3(7):253-259.

13. Davies OA, Allison ME, Uyi HS. Bioaccumulation of heavy metals in water, sediment and periwinkle (Tympanotonus fuscatus varradula) from the Elechi Creek, Niger Delta. African Journal of Biotechnology. 2006;5(10):968-973.

14. Ayenimo JG, Adeeyinwo CE, Amoo IA, et al. A Preliminary Investigation of Heavy Metals in Periwinkles from Warri River, Nigeria. Journal of Applied Sciences. 2005;5:813-815.

15. Nwabueze AA, Nwabueze EO, Okonkwo CN. Levels of Petroleum Hydrocarbons and some Heavy Metals in Tissues of Tympanotonus fuscatus periwinkles from Warri river of Niger Delta Area of Nigeria. $J$ Appl Sci Environ Manage. 2011;15(1):75-78. 
16. Onwuli DO, Ajuru G, Holy B, et al. The concentration of Lead in Periwinkle (Tympanotonos fuscatus) and River sediments in Eagle Island River, Port Harcourt, Rivers State Nigeria. American Journal of Environmental Protection. 2014;2(2):37-40.

17. Ikejimba CC, Sakpa S. Comparative study of some heavy metals' concentrations in water and Tympanotonusfuscatusvar radula samples of Egbokodo River, Warri, Nigeria. International Journal of Modern Biological Research. 2014;2:7-15.

18. Aigberua A, Tarawou T. Assessment of Heavy Metals in Muscle of Tilapia zilli from Some Nun River Estuaries in the Niger Delta Region of Nigeria. Academic Journal of Chemistry. 2017;2(9):96-101.

19. Izah SC, Aigberua AO. Comparative Assessment of selected heavy metals in some common edible vegetables sold in Yenagoa metropolis, Nigeria. Journal of Biotechnology Research. 2017;3(8):66-71.

20. Izah SC, Bassey SE, Ohimain EI. Assessment of Some Selected Heavy Metals in Saccharomyces cerevisiae Biomass Produced from Cassava Mil Effluents. EC Microbiology. 2017;12(5):213-223.

21. Izah SC, Bassey SE, Ohimain EI. Removal of Heavy Metals in Cassava Mill Effluents with Saccharomyces cerevisiae isolated from Palm Wine. MOJ Toxicology. 2017;3(4):00057.

22. Horsfall MJ, Horsfall MN, Ayebaemi IS. Speciation of Heavy Metals in Inter-tidal Sediments of the Okrika River System, Rivers State, Nigeria. Bull Chem Soc Ethiop. 1999;13(1):1-9.

23. Inyang IR, Akio K, Izah SC. Effect of dimethoate on lactate dehydrogenase, creatinine kinase and amylase in Clarias lazera. Biotechnological Research. 2016;2(4):155-160.

24. Inyang IR, Izah SC, Johnson DT, et al. Effects of Lambda cyhalothrin on some electrolytes and metabolites in organs of Parpohiocephalusobscurus. Biotechnological Research. 2017;3(1):6-10.

25. Inyang IR, Okon NC, Izah SC. Effect of glyphosate on some enzymes and electrolytes in Heterobranchusbidosalis (a common African catfish) Biotechnological Research, 2016;2(4):161-165.

26. Agedah EC, Ineyougha ER, Izah SC, et al. Enumeration of total heterotrophic bacteria and some physico-chemical characteristics of surface water used for drinking sources in Wilberforce Island, Nigeria. Journal of Environmental Treatment Techniques. 2015;3(1):28-34.

27. Ogamba EN, Izah SC, Oribu T. Water quality and proximate analysis of Eichhorniacrassipes from River Nun, Amassoma Axis, Nigeria. Research Journal of Phytomedicine. 2015;1(1):43-48.

28. Ben Eledo VN, Kigigha LT, Izah SC, et al. Bacteriological Quality Assessment of Epie Creek, Niger Delta Region of Nigeria. International Journal of Ecotoxicology and Ecobiology. 2017;2(3):102-108.
29. Ben Eledo VN, Kigigha LT, Izah SC, et al. Water quality assessment of Epie creek in Yenagoa metropolis, Bayelsa state, Nigeria. Archives of Current Research International. 2017;8(2):1-24.

30. Seiyaboh EI, Izah SC. Bacteriological assessment of a tidal creek receiving slaughterhouse wastes in Bayelsa state, Nigeria. Journal of Advances in Biology and Biotechnology. 2017;14(1):1-7.

31. Seiyaboh EI, Izah SC. Review of Impact of Anthropogenic Activities in Surface Water Resources in the Niger Delta region of Nigeria: A case of Bayelsa state. International Journal of Ecotoxicology and Ecobiology. 2017;2(2):61-73.

32. European Union. The Commission of the European Communities, Commission regulation, (EC) No. 22112002 amending regulation (EC) No. 466/2001 setting maximum levels For certain contaminants in food stuff in order to protect public health. Official Journal of the European Communities 7.2.2002,L37/5-L37/6, 2002.

33. Senarathne P, Pathiratne KAS. Accumulation of heavy metals in food fish, Mystusgulio inhabiting Bologoda Lake, Sri Lanka. Sri Lanka Journal of Aquatic Science. 2007;12:61-75.

34. Senarathne P, Pathiratne KAS, Pathlratne A. Heavy metal levels in food fish, Etroplussuratensis inhabiting Bolgoda Lake, Sri Lanka. Vidyodaya Journal of Science. 2006;13:115-126.

35. Philips DJH. Developing country aquaculture-trace chemical contaminants and public health concerns. In: Environment and Aquaculture in Developing Countries. Pullin RSV, Rosenthal H and Maclean JL, editors. 1993;31:296-311

36. Food and Agricultural Organization/ World Health Organization (FAO/ WHO). Evaluation of certain food additives and the contaminants mercury, lead and cadmium, WHO Technical Report, Series No. 505. 1989.

37. Elnabris KJ, Muzyed SK, El Ashgar NM. Heavy metal concentrations in some commercially important fishes and their contribution to heavy metals exposure in Palestinian people of Gaza Strip (Palestine). Journal of the Association of Arab Universities for Basic and Applied Sciences. 2013;13(1):44-51.

38. World Health Organization (WHO). Malathion in drinking water Background Document for Preparation of WHO Guidelines for Drinking Water Quality. World Health Organization (WHO/SDE/WSH/03.04/103). Geneva. 2003.

39. Anim Gyampo M, Kumi M, Zango MS. Heavy Metals Concentrations in some selected Fish Species in Tono Irrigation Reservoir in Navrongo, Ghana. Journal of Environment and Earth Science. 2013;3(1):109-119.

40. Izah SC, Inyang IR, Angaye TCN, et al. A review of heavy metal concentration and potential health implications in beverages consumed in Nigeria. Toxics. 2017;5(1):1-15. 